\title{
EXPERIMENTAL PROCEDURE FOR SLIP FACTOR DETERMINING AT CONNECTIONS WITH PRELOADED BOLTS
}

\author{
Marina Poposka \\ University "Ss. Cyril and Methodius", Faculty of Civil Engineering, Skopje, Republic of Macedonia, \\ student
}

\section{Borjan Petreski}

University "Ss. Cyril and Methodius", Faculty of Civil Engineering, Skopje, Republic of Macedonia, student

\section{Petar Cvetanovski}

University "Ss. Cyril and Methodius", Faculty of Civil Engineering, Department of Steel Structures, Skopje, Republic of Macedonia, Associate Professor

\section{Denis Popovski}

University "Ss. Cyril and Methodius", Faculty of Civil Engineering, Department of Steel Structures, Skopje, Republic of Macedonia, Assistant

\begin{abstract}
This article presents the advantages of using preloaded bolts in connections of steel structures. First we discussed the main differences between preloaded bolts and shear bolts. Then we explained the categories of shear connections and the categories of friction surfaces, along with their associated surface preparation and slip factor. To connect theory and codes with experiment, we showed the basic expressions used to calculate the design resistance of preloaded bolts and compared the design resistance of shear bolts. The slip factor was tested according to EN 1090-2:2008, Annex G, for two series of specimens, identical to those used in bridges in the Republic of Albania.
\end{abstract}

Key words: bridges, connections, Eurocode 3, preloaded bolts, slip factor, surface preparation

\section{EKSPERIMENTALNO ODREĐIVANJE FAKTORA PROKLIZAVANJA KOD SPOJEVA S PREDNAPETIM VIJCIMA}

Sažetak: U članku su predstavljene prednosti uporabe prednapetih vijaka u spojevima za čelične konstrukcije. Prvo su predstavljene osnovne razlike između prednapetih i posmičnih vijaka. Zatim su objašnjene kategorije posmičnih spojeva i klase trenja površine, zajedno s pripadnim metodama pripreme površine i faktorima proklizavanja. Kako bi se eksperiment povezao s teorijom i normativnom podlogom, prikazani su osnovni izrazi korišteni za utvrđivanje otpornosti prednapetih vijaka te su dobivene otpornosti uspoređene s otpornostima posmičnih vijaka. Ispitivanje faktora proklizavanja provedeno je u skladu s EN 1090-2:2008, Dodatak G, a ispitane su dvije skupine uzoraka koje su jednake spojevima korištenim u mostovima u Republici Albaniji.

Ključne riječi: mostovi, spojevi, Eurocode 3, prednapeti vijci, faktor proklizavanja, priprema površine 


\section{Introduction}

Preloaded bolts were used for the first time after World War II as a substitute for the old rivets used as fasteners on the bridges in the United States of America. They were soon used in bolted connections, especially in structures exposed to dynamic load such as bridges [1].

One main advantage of preloaded-bolt connections is their stiffness. Contrasting shear-bolt connections, where the capacity mechanism activates after a certain slip in the connection, preloaded bolts do not slip until the activated slip resistance is overcome. This is the main reason for their good behavior during dynamic loading [2].

The principles for designing preloaded-bolt connections and calculating their bearing capacity are given in Eurocode EN 1993-1-8 [3]. This code classifies shear connections into three categories (Table 3.2 EN 1993-1-8) [1]. Category A concerns connections with shear bolts that work without requiring preloading or special provisions for the contact surfaces. Categories B and C concern preloaded bolts. Category B includes connections that disallow slipping by the working-stress approach, while category $C$ deals with connections that limit slipping by the limit-state approach. The bearing capacity of a preloaded bolt depends much on the slip factor at the contact surfaces of the connection. There are four categories of friction surfaces: $A, B, C$, and $D$, which have different surface treatments and slip factors, as shown in Table 1.

Table 1. Classes of friction surfaces for preloaded bolts [3]

\begin{tabular}{|l|c|c|}
\hline \multicolumn{1}{|c|}{ Surface Treatment } & Class & Slip Factor $(\mu)$ \\
\hline Surfaces blasted with shot or grit with loose rust removed, not pitted & A & $\geq 0.50$ \\
\hline $\begin{array}{l}\text { Surfaces blasted with shot or grit: } \\
\text { a) Spray-metallized with aluminum or zinc-based product }\end{array}$ & B & $\geq 0.40,<0.50$ \\
b) With alkali-zinc silicate paint, thickness of $5080 \mu \mathrm{m}$ & & $\geq 0.30,<0.40$ \\
\hline Surfaces cleaned by wire brush or flame cleaning, with loose rust removed & C & $\geq 0.20,<0.30$ \\
\hline Surfaces as rolled (untreated) & D & \\
\hline
\end{tabular}

To classify a surface treatment, its slip factor must be experimentally determined. The experimental procedure to determine the slip factor is prescribed in the European pre-standard EN 1090-2:2008, Annex G [4]. In accordance with this procedure, we analyzed the slip factor of surfaces blasted with alkali-zinc silicate anti-rust paint. This testing was performed to meet the production and assembly needs for steel structures used to construct road bridges in the Republic of Albania.

The samples were prepared by Metalec A.D. Prilep, Republic of Macedonia. The organization, measurements, and data processing were performed by the authors. The tests were performed with a pressmachine at the Institute for Testing Materials and Development of New Technologies "Skopje", A.D. Skopje [5].

\section{Comparing the Bearing Capacity of Bolts}

To illustrate the characteristics of preloaded bolts, we calculated the bearing capacity of a single bolt (M16/10.9) as preloaded and an appropriate shear bolt (M16/5.6). We also calculated the bearing capacity of the preloaded bolt used as a shear bolt.

When testing the slip factor, we used standard materials and dimensions as prescribed in the European pre-standard EN 1090-2:2008, Annex G [4]. Figure 1 shows a schematic of the specimen used for testing. 


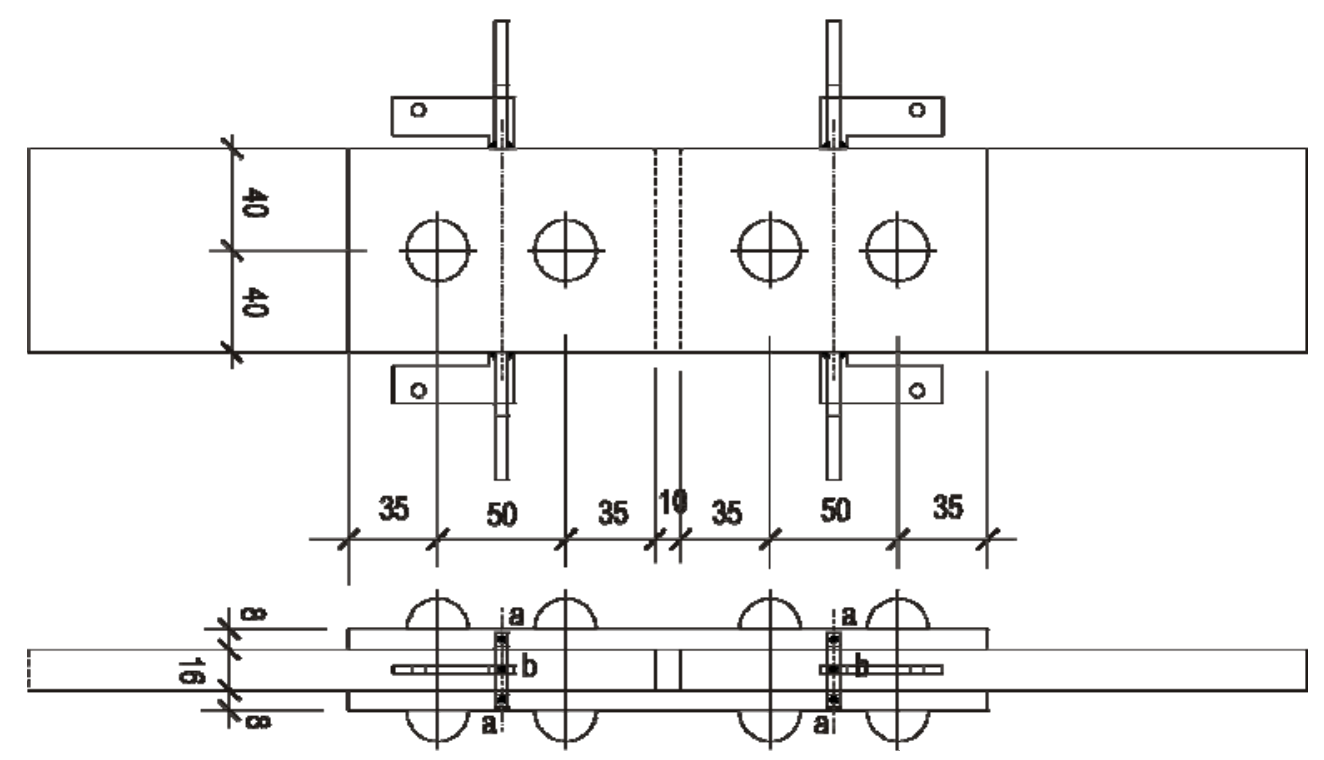

Figure 1. Schematic of the tested specimen (connection)

\subsection{Shear capacity}

The shear capacity of a double shear bolt (M16/10.9), according to EN 1993-1-8 (3.6), is calculated by Eq. (1):

$$
F_{v, R d}=2 \cdot \frac{\alpha_{v} \cdot f_{u b} \cdot A}{\gamma_{M 2}}=2 \cdot \frac{0.6 \cdot 1000 \cdot 201}{1.25} \cdot 10^{-3}=193.0 \mathrm{kN}
$$

$\alpha_{v}$ for classes of bolts 4.6, 5.6, and 8.8: $\alpha_{v}=0.6$; for classes of bolts 4.8, 5.8, 6.8, and 10.9: $\alpha_{v}=0.5$ where the shear plane passes through the unthreaded portion of the bolt: $\alpha_{v}=0.6$

$f_{u b}$ ultimate tensile strength of bolt

A gross cross-section of bolt

$\gamma_{M 2}$ partial safety factor for joints; resistance of bolt.

The bearing resistance of the bolt, which depends on the geometry and type of connection, for steel grade S235 [6] is shown by Eq. (2):

$$
\begin{aligned}
& F_{b, R d}=\frac{k_{1} \cdot \alpha_{b} \cdot f_{u} \cdot d \cdot t}{\gamma_{M 2}}=\frac{2.5 \cdot 0.65 \cdot 360 \cdot 16 \cdot 16}{1.25} \cdot 10^{-3}=119.8 \mathrm{kN} \\
& k_{1}=2.8 \cdot \frac{e_{2}}{d_{0}}-1.7 \text { (as edge bolts) or } 2.5 \text { (minimum value) }
\end{aligned}
$$

$e_{2}$ edge distance from the center of a fastener hole to the adjacent edge of any part, measured at right angles to the direction of load transfer

$d_{0}$ hole diameter of bolt (for bolt with $d=16 \mathrm{~mm}, d_{0}=18 \mathrm{~mm}$ )

$$
k_{1}=2.8 \cdot \frac{40}{18}-1.7=4.52>2.5 \Rightarrow k_{1}=2.5
$$

$\alpha_{b}$ smallest value of Eq. (4), Eq. (5), or $1.0 \Rightarrow \alpha_{b}=0.65$ 


$$
\alpha_{d}=\frac{e_{1}}{3 d_{0}}=\frac{35}{3 \cdot 18}=0.65
$$

$e_{1}$ edge distance from center of a fastener hole to the adjacent end of any part, measured in the direction of load transfer

$$
\frac{f_{u b}}{f_{u}}=\frac{1000}{360}=2.78
$$

$f_{u} \quad$ ultimate tensile strength of plate

$d$ diameter of bolt

$t \quad$ wall thickness of member

The pressure bearing capacity of the bolt is dominant (the smaller value of $F_{v, R d}$ and $F_{b, R d}$ ), $F_{b, R d}=119.8$

$\mathrm{kN}$; because the connection comprises two bolts, its capacity is $239.6 \mathrm{kN}$. The M16/5.6 shear bolt had the same pressure bearing capacity as the M16/10.9 shear bolt, but its shear capacity was reduced from 1000 to $500 \mathrm{MPa}$ at $96.5 \mathrm{kN}$. These results show that using high-quality bolts is justified if the shear capacity is dominant.

\subsection{Slip Resistance}

The slip resistance of a double shear bolt (M16/10.9), according to EN 1993-1-8 (3.6), is calculated by Eq. (6):

$$
F_{s, R d}=\frac{k_{s} \cdot n \cdot \mu}{\gamma_{M 3}} \cdot F_{p, C}=\frac{k_{s} \cdot n \cdot \mu}{\gamma_{M 3}} \cdot 0.7 \cdot f_{u b} \cdot A_{s}=\frac{1.0 \cdot 2 \cdot 0.3}{1.25} \cdot 0.7 \cdot 1000 \cdot 157 \cdot 10^{-3}=52.8 \mathrm{kN}
$$

$k_{s} \quad$ factor depending on the size of the hole, for bolts in normal holes $k_{s}=1.0$

$n \quad$ number of friction planes

$\mu$ slip factor

$F_{p, C}$ preloading force

$A_{s} \quad$ tensile stress area of bolt

$\gamma_{M 3}$ partial safety factor for joints; slip resistance (category $\mathrm{C}$ ).

The resulting force $(52.8 \mathrm{kN})$ is the slip resistance of the bolt. This value places the connection in category $\mathrm{C}$, which limits slipping by the limit-state approach. For a category B connection, which prevents slipping by the working-stress approach, rather than using the partial safety factor $\gamma_{M 3}=1.25, \gamma_{M 3, s e r}=1.10$ was used. In this case the slip resistance of the bolt was $60.0 \mathrm{kN}$. The bearing capacity of category B connection with two bolts was 120 $\mathrm{kN}$, while for category $\mathrm{C}$ it was $105.6 \mathrm{kN}$. The bearing capacity of the slip-resistant connections was considerably smaller than of those where slipping was allowed (category A). The slip factor is particularly important for the slip resistance of a bolt. In this illustrative example, we consider $\mu=0.3$.

\section{Experimental Determination of Slip Factor}

\subsection{Specimen Preparation and Testing}

Bridges in the Republic of Albania use preloaded bolts with anti-rust alkali-zinc silicate paint with a thickness of 60 $\mu \mathrm{m}$ (total of two coats). These connections are produced by Metalec A.D., Prilep, Republic of Macedonia.

For calculations, we assumed a slip factor of $\mu=0.3$. Two series of three samples each (Fig. 1) with an M16 bolt diameter were produced. High-quality bolts (10.9) made from S235 material were used.

The anti-rust protection was coated in two layers on a gritted surface. Before assembling the samples and after testing, we measured the thickness of the anti-rust coatings. The thickness was measured at multiple points on the tangent surfaces on the upper and lower parts of the connection, as shown in Figs. 1 and 2. 


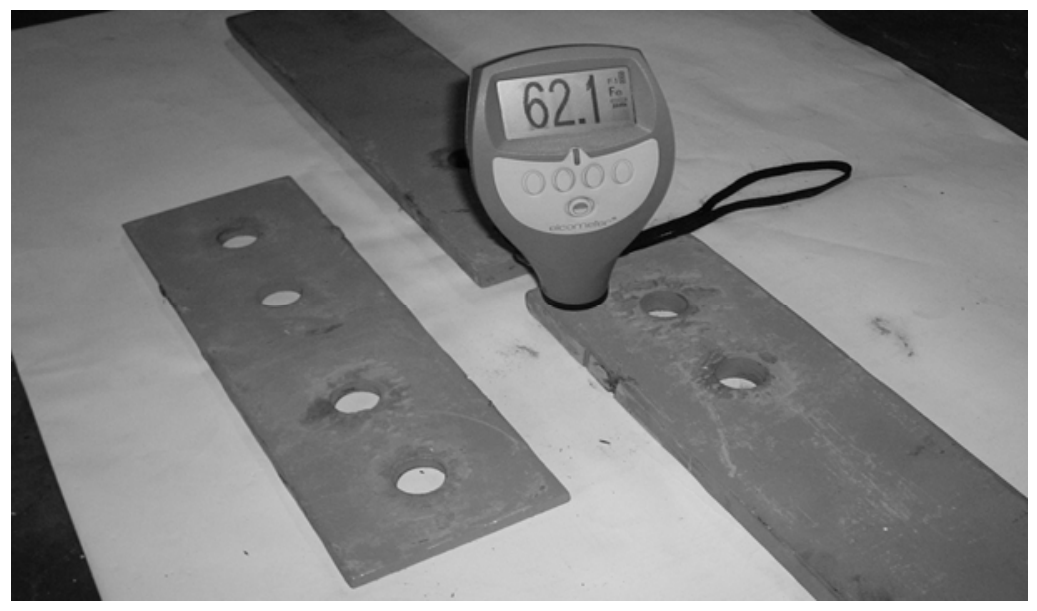

Figure 2. Measuring the paint thickness

The bolts were tightened by a torque wrench according to a standardized procedure and torque value, as shown in Eqs. (7) and (8):

$$
\begin{array}{ll}
F_{p, C}=0.7 \cdot f_{u b} \cdot A_{s}=0.7 \cdot 100 \cdot 157 \cdot 10^{-3}=110 \mathrm{kN} & \text { (tightening force) } \\
M_{p, C}=0.16 \cdot F_{p, C} \cdot d=0.16 \cdot 110 \cdot 16=282 \mathrm{kNm} & \text { (torque) }
\end{array}
$$

On the outside edges of the sample holders were welded comparators, used to measure the slipping between the inner lamella $(\mathrm{d}=16 \mathrm{~mm})$ and outer lamella, as shown in Fig. 3. The mechanical comparators measured slip with an accuracy of $1 / 100 \mathrm{~mm}$.

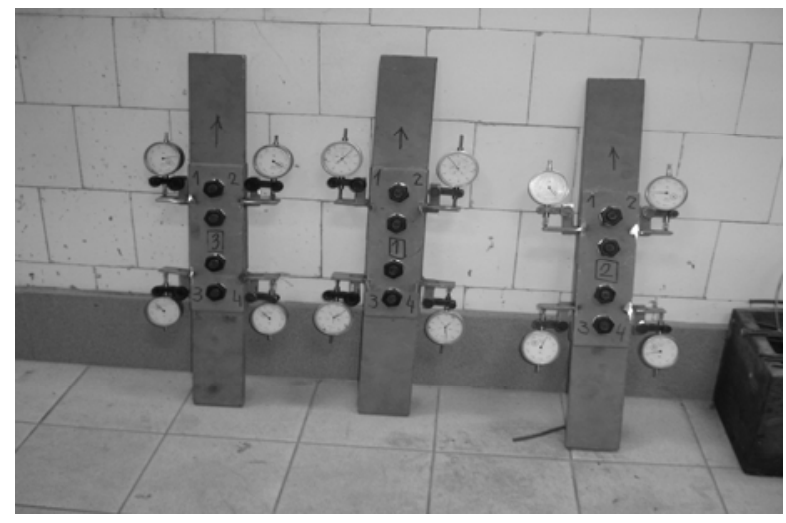

Figure 3. Samples prepared for testing

The samples were mounted on a universal press machine, which applied tensile force in defined steps according to EN 1090-2:2008, Annex G, as shown in Fig. 4. Figure 5 shows the results of these tests in a forcedisplacement diagram.

After each increase in tensile fore, the slipping was measured. The medium value of the two upper, i.e. lower comparators is taken as representative. The prescribed procedure defines slip exhaustion as slip (displacement) of $0.15 \mathrm{~mm}$. 


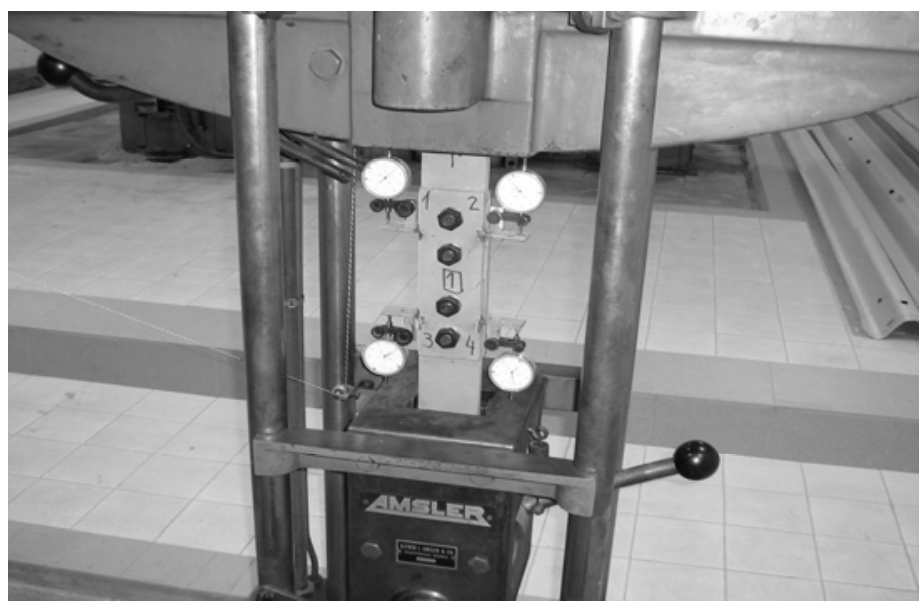

Figure 4. Sample prepared for testing

$\lceil\mathrm{kN}\rceil$

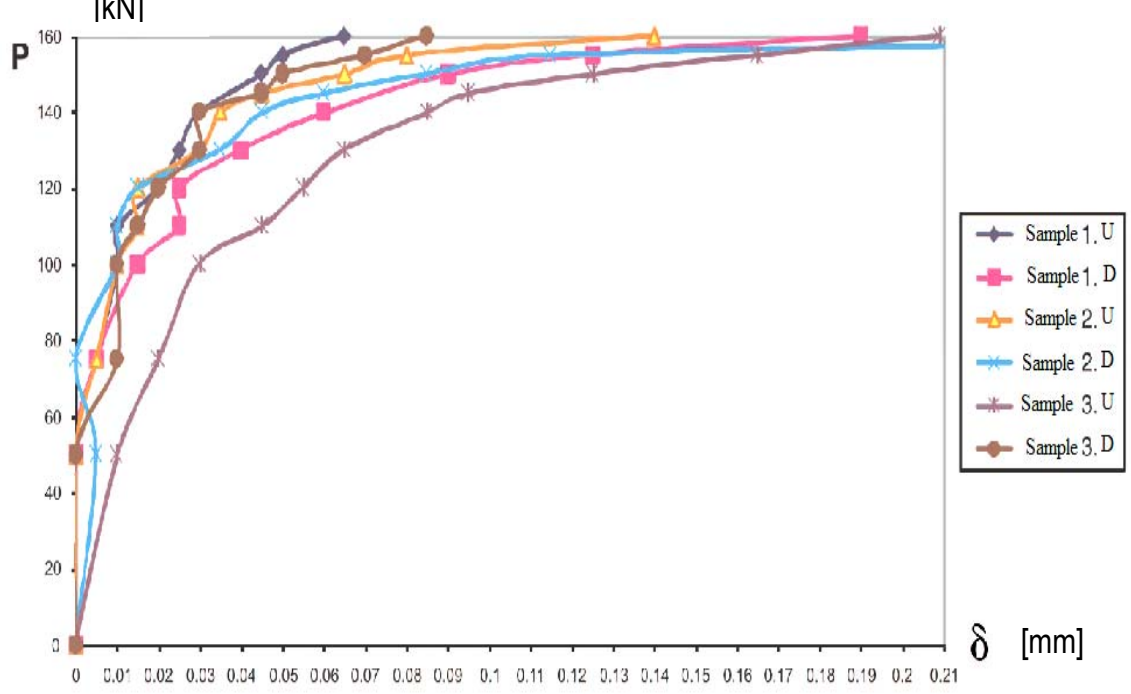

Figure 5. Tensile test results, showing displacement with applied force

\subsection{Measured Results}

The slip factor was determined by the relation between the applied tensile force, for which no slipping greater than a mean of $0.15 \mathrm{~mm}$ was detected, and the tightening force $(4 \times 110=440 \mathrm{kN})$. Table 2 gives the measured values.

\section{Table 2. Measured slip factors}

\begin{tabular}{cccc}
\hline & & Force $[\mathrm{kN}]$ & Slip factor $\mu$ \\
\hline \multirow{2}{*}{ Sample 1 } & up & 180 & 0.409 \\
& down & 155 & 0.352 \\
Sample 2 & up & 165 & 0.375 \\
& down & 160 & 0.364 \\
Sample 3 & up & 150 & 0.341 \\
& down & 160 & 0.364 \\
\hline
\end{tabular}


The mean measured slip factor was 0.3674 with a standard deviation of 0.0214 . The characteristic value of the measured slip factor is presented in Eq. (9):

$$
\mu_{c}=0.3674-2.05 \times 0.0214=0.3235
$$

\section{Conclusion}

Preloaded bolts are convenient connections in structures that require connections with high stiffness, especially in structures exposed to dynamic loads (cyclic loading). The key parameter for slip resistance in preloaded-bolt connections is the slip factor of the contact surfaces. The highest slip factor (category A) was obtained for surfaces treated with grit and protected with an anti-rust coating, applied by spray-metallization with aluminum- or zinc-based products. Applying an alkali-zinc silicate paint as anti-rust protection decreased the slip factor (to categories $\mathrm{B}, \mathrm{C}$ ). Connections with this surface treatment generally had a slip factor of category $\mathrm{C}$. Figure 6 shows the contact surfaces of the specimens after the testing.

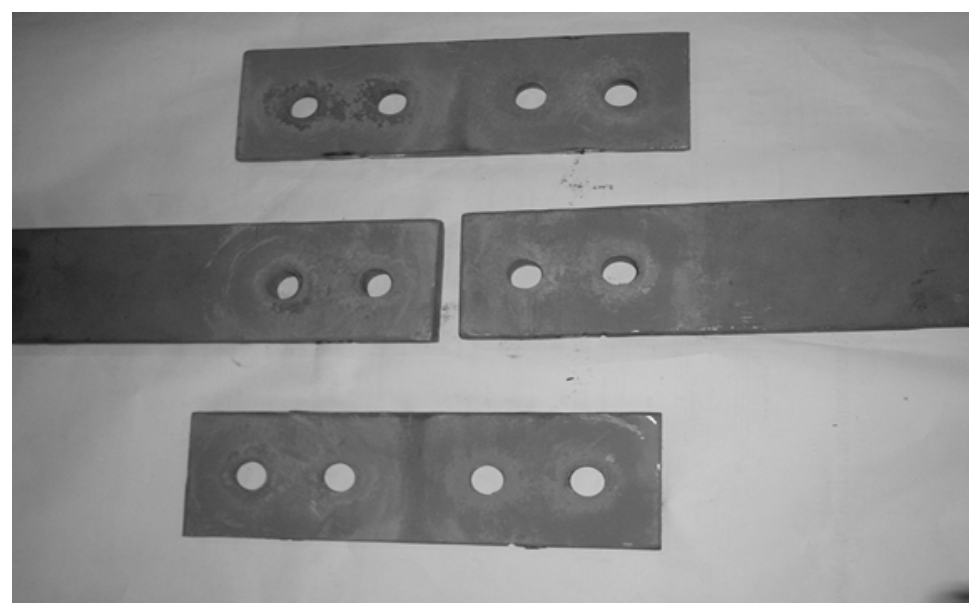

Figure 6. Contact surfaces after testing

\section{References}

[1] Steelworks, http://www.engineeringcivil.com/theory, Accessed 12 March 2013

[2] Filipovski, A. 2000: Basics of Steel Structures, AD Napredok, Tetovo, Republic of Macedonia

[3] EN 1993-1-8, Design of steel structures - Part 1-8: Design of joints, CEN Brussels 2005

[4] EN 1090-2:2008 Execution of steel structures - Part 1: General rules and rules for buildings, CEN Brussels 2008

[5] Cvetanovski P. 2013: Personal communication, University "Ss. Cyril and Methodius," Faculty of Civil Engineering, Department of Steel Structures, Skopje, Republic of Macedonia

[6] EN 1993-1-1, Design of steel structures - Part 1-1: General rules and rules for building, CEN Brussels 2005 